\title{
The Regulatory Welfare State in Pension Markets: Mitigating High Charges for Low-Income Savers in the United Kingdom and Israel
}

\author{
AVISHAI BENISH*, HANAN HABER** AND ROTEM ELIAHOU*** \\ * Paul Baerwald School of Social Work and Social Welfare, The Hebrew University of \\ Jerusalem, Mount Scopus, Jerusalem 91905, Israel \\ email: avishai.benish@mail.huji.ac.il \\ ** Department of Government and Centre for Analysis of Risk and Regulation, London School \\ of Economics and Political Science, Houghton Street, London, WC2A 2AE, UK \\ email: h.y.haber@/se.ac.uk \\ *** Graduate of Integrative Program: Philosophy, Economics, Political Science, The Hebrew \\ University of Jerusalem, Mount Scopus, Jerusalem 91905 \\ email: rotem.eliahou@mail.huji.ac.il
}

\begin{abstract}
How does the rising 'regulatory welfare state' address social policy concerns in pension markets? This study examines this question by comparing the regulatory responses to high charges paid by low-income workers in pension markets in the UK and Israel. In the UK, with the recognition that the market would not cater to low-income workers, the regulatory response was the creation of a publicly operated low-cost pension fund (NEST), a 'public option' within the market. This allowed low-income workers access to a low level of charges, previously reserved for high-income and organised workers. In Israel, regulation sought to empower consumers, while providing minimal social protection by capping pension charges at a relatively high level, thereby leaving most of the responsibility for reducing the charges with the individual saver. By comparing these two cases, the article develops an analytical framework for the study of the regulatory welfare state, making two contributions. First, it highlights different types of regulatory citizenship: minimal regulatory social protection as opposed to a more egalitarian approach. Second, it identifies an overlooked regulatory welfare state strategy: creating 'public option' arrangements, whereby a state-run (but not funded) service operates within the market.
\end{abstract}

\section{Introduction}

In recent decades we have witnessed the rise of the regulatory state in social welfare (Gilbert, 2005; Leisering and Mabbett, 2011; Haber, 2011; Levi-Faur, 2013, 2014). Since as early as the mid-1960s, and especially since the 1990s, privatisation and marketisation have shifted markedly away from the provider (or positive) state - in which direct state provision and financing are the primary policy tools 
of social welfare - towards a new structure, in which market actors occupy a growing share of social welfare provision. Under this new structure, which can be referred to as a 'regulatory welfare state', regulation becomes a key policy tool in safeguarding social welfare norms and outcomes, especially where the most vulnerable beneficiaries are concerned.

This article explores the interaction between these two perceptions of the state's role through a case study of the regulation of private old-age pensions - in particular, the regulation of their management charges. As evident from Leisering and Mabbett's (2011) study of the regulation of pensions in Germany and the UK, this is one of the most instructive fields for observing how the market logic of the regulatory state and the norms of social citizenship of the welfare state interact. The field of old-age pensions has moved strongly towards privatisation and marketisation, particularly following the worldwide promulgation of pension reform programmes based on the 1994 World Bank report. As a result, we see an increasing portion of private pension funds in the pension mix, and a shift from defined benefit schemes (DB) to defined contribution schemes (DC), which generally put a higher burden of the social risks of old-age on the individual savers.

The commercialisation of old-age savings warrants increased attention to their regulation. Traditionally, such regulation includes economic regulation of the market for these services to address economic concerns of sustainability and efficiency and ensure consumer protection. However, the privatisation of pensions has resulted in new inequities and risks to citizens' financial security, prompting calls for 'social regulation' as well (Leisering, 2011, 2012; Mabbett, 2011, 2012). The need for social forms of regulatory intervention is particularly apparent with regard to low-income savers, who can be expected to pay higher charges due to their weaker market power and lower financial literacy. This is a policy problem that regulators in many countries are increasingly struggling with (OECD, 2009: 144)

In this article we ask, therefore, whether pension regulators address the challenges faced by low-wage pension savers in terms of pension charges - and, if so, how. Through a comparative analysis of the pension sectors in the UK and Israel, we ask what policy goals and instruments were set for the regulation of the private pension scheme charges and how these varied over time and across cases.

The comparison of the Israeli and the UK cases offers a useful perspective, given their similarities and differences. In both countries, there is a similar initial institutional setup, a basic layer of universal social insurance, and in both cases this has been deemed inadequate by policy makers who have sought to amend the situation using market-based solutions. The two countries differ, however, in their approach to welfare: the UK has a traditionally liberal, minimal welfare state regime, while Israel, although rooted in social democratic traditions, is increasingly committed to market solutions in social welfare (Gal, 2010). 
By comparing these two countries, the study makes two contributions. First, it recognises the different levels of social egalitarianism that regulatory welfare may assume. While previous studies have found arrangements mainly aim to provide minimal levels of market access to 'unattractive' customers, this study differentiates between the minimal regulatory social protection found in the Israeli case and the (somewhat surprising) more egalitarian approach in the UK one. Second, by analysing the UK example of NEST as a publicly operated pension fund in the market, the work offers a nuanced theoretical framework for the study of different kinds of regulatory welfare policy tools and delivery methods, highlighting the usually overlooked strategy of creating a 'public option' to provide services within the market.

The paper is divided into six parts. Part I is a theoretical and analytical section explaining the relationship between regulation and welfare and varieties of regulatory welfare. Part II gives the context of pension privatisation and the study of the regulatory welfare state in this field. Parts III and IV present cases of regulation of pension charges in the $\mathrm{UK}$ and in Israel, respectively. Part $\mathrm{V}$ compares and discusses these two cases. Part VI presents the conclusion.

\section{Theoretical framework: when the welfare state meets the regulatory state}

Traditionally, in both social policy and regulation scholarship, the welfare state and the regulatory state were often conceived as antagonistic realms with irreconcilable logics. The term welfare state has many meanings in the literature, but is usually understood as a state that assumes social responsibility for the well-being of its citizens (Leisering, 2011). At the normative level, the welfare state is rooted in egalitarian and collectivist ideas of securing basic human needs and promoting equality, solidarity and social justice. At the institutional level, it is associated with redistribution by the state through fiscal means of taxation and spending and the direct delivery of publicly funded benefits and services through public bureaucracies (Mabbett, 2010).

A central feature of welfare states is the degree to which they modify the distribution of resources generated in the market to enable de-commodification, and allow individuals and families access to goods and services as a matter of right, rather than having to rely on the market. As Esping-Andersen's (1990) seminal work portrays, welfare states vary on this matter. While, in liberal welfare states, the focus is on means-tested poverty relief measures, with relatively low levels of de-commodification, social-democratic welfare states aspire towards higher levels of de-commodification through universal and more adequate levels of benefits (Esping Andersen, 1990: 21-23).

This understanding of the state's role is captured in Marshall's concept of 'social citizenship'. According to Marshall, 'social rights in their modern form imply an invasion of contract by status, the subordination of market price to social 
justice, the replacement of the free bargain by the declaration of rights' (cited in Dean, 2015: 5). Marshall highlights the place of the public sector as the arena in which welfare can be adequately and fairly delivered, but he acknowledges the role of 'industrial citizenship', that is, the establishment of social rights through collective agreements between employers and unions (Trampusch, 2007).

The regulatory state model, meanwhile, is usually based on a quite different approach. At the normative level - as Majone points out (1997) in his definitive work on the subject - the regulatory state follows criteria of economic efficiency while keeping politics of equality out. In addition, the regulatory state adopts norms of choice and customer sovereignty to enable consumers to realise their preferences and ensure their access to the market. At the institutional level, the regulatory state delegates control to market actors and uses competition as a chief means of promoting the goals of efficiency, autonomy and individual choice (Benish and Levi-Faur, 2012; Levi-Faur and Gilad, 2004). Under this model, the use of regulation as a policy tool is mainly for 'economic regulation', i.e., correcting market failures, increasing transparency and protecting consumers from unfair market practices. Thus the regulatory state, as conceptualised by Majone and others, is essentially a neoliberal state of limited government by third-party proxies, concerned first and foremost with efficiency and choice by means of competition.

These analytical distinctions between the normative and the institutional characterisation of the welfare state and the regulatory state are, of course, more complex in reality. The point is that, traditionally, the state-centred welfare state and the market-centred regulatory state were commonly perceived as separate concepts of the state, with social policies often perceived as 'politics against markets' (Leisering, 2012: 141).

Recent literature, however, both in the study of social policy and of the regulatory state, has brought these two concepts together, introducing what can be referred to as a 'regulatory welfare state.' For instance, in the social policy literature, Gilbert's (2005) enabling state model suggests the state may provide social protection by regulating private activity in the financing and delivery of social benefits, a notion demonstrated in the UK Labour party policy of 'welfare ends through market means' (Taylor-Gooby et al., 2004). Similarly, in the regulation literature, Levi-Faur $(2013,2014)$ argues, in contrast to Majone's conception of the regulatory state, that the regulatory state may pursue different goals, including the provision of welfare, and the welfare state may use different tools. This conceptual split between the goals and tools of welfare and regulatory states opens up a new space in which the regulatory state and welfare state can coexist.

A review of the literature reveals two main strategies of the regulatory welfare state. The first is the use of quasi-markets through competitive contracting or vouchers (Le Grand, 1991). The funding in these 'welfare markets' arrangements remains basically public (Taylor-Gooby et al., 2004), but regulatory and market- 
mimicking approaches are adopted to steer these services, leading to 'the entry of the regulatory state into the welfare state' (Mabbett, 2010: 217; see also: Benish 2010, 2014). In such instances, the decoupling of public funding and state delivery creates a model of service delivery in which the state funds services delivered through the market.

The second is the use of legal regulatory tools of rulemaking to ensure the access of individuals and families to certain goods and services in the market what can be seen as de-commodification through regulatory means. For instance, in the fields of electricity and water in Israel, state regulations task service providers with the social role of providing targeted, minimal social measures, such as social tariffs and discounts for vulnerable citizens and the prevention of service disconnection due to non-payment resulting from social hardship (Haber, 2011, 2016). Similarly, among other measures, regulatory tools have been increasingly used to assist vulnerable mortgage borrowers in avoiding repossession of their homes in the private housing sector in the UK (Haber, 2015). These instances of the provision of services through regulated markets demonstrate how non-fiscal tools can be used in the market for social welfare purposes, even though they represent a low level of de-commodification, mainly for poverty relief (typical of 'liberal' welfare states in Esping-Andersen's framework).

\section{The regulatory welfare state in the context of pension privatisation}

An increasingly rich social policy literature illustrates the ongoing privatisation of pensions and the shift of responsibility for old-age social security from the state to savers and private actors, particularly in the financial industry (e.g., Ebbinghaus, 2011; Frericks, 2013; Mann, 2005). The shift from public pay-as-you-go pensions to private pensions has been chiefly pushed by international organisations and economic policy experts who argue for reform that will guarantee long-term financial and economic sustainability in ageing societies. For instance, the World Bank widely propagated a three-pillar model of old-age pensions in which individual retirement income is drawn from a public-private mix of sources (Ebbinghaus, 2011; but see also Leimgruber, 2012). While pension privatisation is a product of dire demographic predictions persistently pointing to an impending public pension crisis, it is also derived from a wider welfare reform agenda of activation and responsibilisation, i.e., the idea that everyone can be enabled to plan ahead for retirement and become an active consumer citizen (Mann, 2005). According to this line of reasoning, once 'passive recipients' become 'active choice makers', responsibility for a good retirement income shifts from the state to the individual and to the providers of private pensions in the financial services market.

As a result, market-oriented private pensions, which played only a marginal role in the past, have become part of the institutionalised governance of old-age protection. These 'hybrid pension systems' are designed and regulated differently across countries, and the differences significantly determine the degree of social 
protection of citizens and the number of pensioners with adequate pensions (Frericks, 2013). Thus, even though the state has retreated from the public responsibility of financing and administering state pensions, the need for and importance of the regulatory role of the state and societal control of private pensions has increased (Ebbinghaus, 2011).

Leisering and Mabbett (2011) provide the most comprehensive theoretical and empirical account of the dynamics of regulatory welfare in the context of privatised pensions (see also Leisering, 2011, 2012; Mabbett, 2011, 2012). In their empirical exposition of the regulation of private pensions in Germany and the UK, they show that, paradoxically, as a result of pension privatisation in these countries, pension markets have become more politicised and more socialised. They identify and characterise new public policies of private pensions that go well beyond the types of corrections of market failures or customer protection usually associated with economic regulation, to include social regulation promoting social goals, especially in terms of alleviating poverty and addressing inequality. Meanwhile, the regulatory instruments in the pension field have gone beyond traditional modes of legalistic standard-setting and monitoring, moving towards such methods as direct subsidies to the private pensions of low-income citizens, as in Germany (Berner, 2011), or pedagogical interventions aimed at educating and advising citizens about saving for retirement.

At the same time, however, Leisering and Mabbett note that, in the process of socialising private pensions, the meaning of the 'social' has been modified and diluted to conform with norms borrowed from the liberal and civil realms. In this process, the focus of regulation is not so much on welfare outcomes but on regulating access, procedures and the governance of the pension organisations. Taylor-Gooby (2011) stresses this limitation of the regulatory welfare state, arguing the marketisation embedded in the regulatory state inherently undermines the solidaristic orientation of the welfare state, so that the very forces promoting regulatory welfare also circumscribe its successes (see also Taylor-Gooby et al., 2004).

Against this background, the following two sections explore the regulation of pension scheme charges in the UK and Israel, focusing on the nature of the policy tools and aims and examining how these vary over time.

\section{Regulating pension charges in the UK Background}

A 2004 report by the UK Pensions Commission dubbed the UK pension system the 'most complex' system in the world, given its many layers of public and private provision and frequent regulatory reforms (Marschallek, 2011). The basic and modest flat-rate state pension layer was established in 1946, as a state-run, universal and flat-rate pension, financed by National Insurance contributions. The government's efforts to supplement this basic flat-rate pension with an earnings-related 'second tier' pension resulted in Labour's 
State Earnings-Related Pension Scheme (SERPS), enacted in 1978. This was funded through National Insurance contributions, but employees were allowed to 'contract out' of SERPS to private pension schemes, provided these could guarantee a pension equal to or exceeding the SERPS pension (Marschallek, 2011: 125). A third layer consists of other private arrangements, including occupational pensions, set up voluntarily by employers which, in their heyday in the 1960s, covered about half of the employed population (Marschallek, 2011: 123-124).

In the 1980s, Thatcher's Conservative government sought to roll back state provision and to expand the role of the market in pensions, as in other areas (Mann, 2005; Taylor-Gooby, 2011). However, misleading sales promotions and various embezzlement scandals undermined the government's efforts, and spurred the beginning of 'hyper regulation', starting with the 1995 Pensions Act (Marschallek, 2011: 108). When Labour returned to power in 1997, it made no attempt to reverse the privatisation of pensions. Instead, it chose to focus state pensions on those in greatest need and to expand private provision for all others. Among other policy steps, it also introduced stakeholder pensions personal pensions designed to meet a wide range of minimum product standards, including a cap of annual charges at 1 per cent of the fund (Marschallek, 2011). The pension system underwent yet further reform in the Pensions Acts of 2007 and 2008. The focus of this paper is one of the programmes introduced in these reforms - the National Employment Savings Trust (NEST).

\section{NEST: creating a public option for low-income earners}

In 2002, the Labour Government formed an independent Pensions Commission, to review the regime of UK private pensions and long-term saving (DWP, 2006: 13). The Commission submitted its report in 2005 and, in the following year, based on that report, the Department for Work and Pensions (DWP) released a white paper on pension reform. The report and the white paper found that no suitable savings options were available to low- and mid-wage workers in the pension market, and that 'the retail financial services industry cannot serve profitably except at Annual Management Charges (AMCs) which are disincentives to saving and which substantially reduce pensions available in retirement' (Pensions Commission, 2005: 3). This lack of profitability was attributed to the high administration, advice and sales costs for providers, and the fact that consumers of these segments of the market often fail to maintain pension contributions in the long run. As the white paper pointed out:

The financial services industry does not generally seek to sell personal pensions to low to moderate earners, particularly if they work for smaller employers, because it is not economic to do so. (DWP, 2006: 43)

The report concludes that while there is competition for high earners and better organised workers who are offered lower management charges (of 0.3-0.5 
per cent or less), there is no such competition for individual low- and middleincome earners, who pay higher charges. The white paper estimates that a person paying the highest level of charges may find their pension fund on retirement worth around 20 per cent less than that of an equivalent wage earner who had paid charges at the lower rate (DWP, 2006: 43).

In their 2005 report, the Pensions Commission concluded that the inherent barriers to serving the low- and middle-income segment on a voluntary basis 'are so severe that they will not be overcome simply by making the state pension system less complex, more understandable and less means-tested. This implies that policies which go beyond pure voluntarism will be required' (Pensions Commission, 2005: 73). However, it did not recommend making pension saving compulsory (see Meyer and Bridgen, 2012; Naczyk and SeeleibKaiser, 2015), but proposed another regulatory instrument: the creation of a national pension saving scheme by the government - the National Employment Savings Trust (NEST) - that would seek to maintain low-cost administrative charges:

The scheme should aim to deliver to all employees and the self-employed the opportunity to save for a pension at the Annual Management Charge (e.g. o.3 per cent per year or less) today enjoyed only by employees of large firms, by public sector employees or by high income individuals (Pensions Commission, 2005: 8).

Based on the Commission's report, the 2006 DWP white paper set out to make it 'easier for more people to save more for their retirement' as the overarching goal of pension reform (DWP, 2006: 16). With regard to private occupational pensions, the white paper's two main proposals were to introduce automatic enrolment for all eligible employees (with the option to opt out), and to create 'low-cost personal accounts to give those without access to occupational pension schemes the opportunity to save' (DWP, 2006: 15). The paper concludes that these reforms would '.. make the system fair, by ensuring access to highquality, low-cost provision for all' (DWP, 2006: 31).

NEST was finally launched in 2010, as a non-departmental public corporation. It was designed as a 'public option' for retirement saving, with a no-frills, low-cost occupational DC pension targeted mainly at low- and middle-income savers (DWP, 2013: 4). Moreover, it is bound by a 'public service obligation' under the EU directive of Services of General Economic Interest meaning that it must accept any employee who wishes to enrol, even if the cost of administering the account is greater than the revenue derived from charges (DWP, 2013: 12). NEST was introduced with the stipulation that, from 2012 onwards, employers must automatically enrol all workers earning more than $\mathfrak{E}_{5}$, ooo per annum in a default fund. Under the scheme, opting out of automatic enrolment is possible, but subject to several conditions that make it more difficult. 


\section{Regulating pension charges in Israel \\ Background}

The Israeli pension system comprises three components. The first is a basic state pension, a universal old-age benefit introduced in 1953, with an income supplement added later for those without other income (Gal, 2002). The second component consists of all occupational pension arrangements - such as the Israeli civil service budgetary pension, old DB pension funds, new DC pension funds, provident funds and 'senior employees insurance' (life insurance policies with a significant savings component). Given the very modest sums provided by the state basic pension, this component is critical to ensuring an adequate level of income in old age. The third component consists of private savings through various schemes, which can be joined voluntarily (Lurie, 2015).

Since 1995, the occupational pension system has undergone a series of radical reforms. At that time, most occupational pension arrangements were managed by the Histadrut - Israel's General Federation of Labour - as DB pension funds; only a minority of the funds were privately managed. When it became apparent that some Histadrut pension funds suffered from significant actuarial deficits, nearing insolvency in some cases, the government and the Histadrut reached an agreement that the state would provide a safety net for those funds, but that henceforth all the Histadrut's funds would be closed to new members. Instead, new members were offered new DC pension funds, which would also be managed by the Histadrut (Lurie, 2015).

In 2003, the government decided to privatise these new funds. This was done in two phases: first, they were nationalised; then, they were sold to private insurance companies in 2004 (Lurie, 2015). As a result, Israel's insurance industry regulator - the Capital Market, Insurance and Savings Division of the Ministry of Finance (CMISD) - became a major player in the regulation of pensions, as the authority responsible for licensing pension firms and regulating their products.

The next major development occurred in 2008, when pension saving was made mandatory. In 2007, the Histadrut and Israel's umbrella employers' association signed a collective agreement that required all members of the organisation to establish occupational pensions for their employees. In 2008, the Minister of Industry, Trade and Employment used his prerogative under Israel's labour law to extend this collective agreement to all employers in Israel (Lurie, 2015).

\section{Management charges in the Israeli context}

Prior to the 2003/4 privatisation reform, the maximum rate for pension fund management charges was set by law at 8 per cent of the monthly contributions. The reform reduced the maximum rate of management charges for the new DC pension funds to 6 per cent of monthly contributions, but allowed for an additional annual amount of 0.5 per cent of the total cumulative fund value, to make the pension market more attractive for private actors, and to encourage 
them to offer higher bids to the government in the privatisation tenders. In practice, it resulted in higher maximum management charges, due to the growth in the cumulative value of the pension funds (Lurie, 2015).

In 2013, average management charges in the pension sector were approximately 3.5 per cent of the monthly contributions, and about 0.3 per cent of the accumulated value of the fund - lower than the maximum rates allowed by law (Ministry of Finance, 2015a). However, a breakdown of these figures shows that 33 per cent of these savers paid the maximum management charges, and a further 12 per cent of savers paid high management charges (Ministry of Finance, 2014b). According to Ministry of Finance estimates, these savers will lose about 20 per cent of the value of their pension funds in comparison with their low-fee counterparts by the time they reach retirement (Arlozerov, 2014). In contrast, low management charges are typically the preserve of employees of large firms, members of powerful employee unions, or high earners who are more profitable for the pension funds, while non-unionised and low-wage employees pay the maximum rate of management charges allowed (Amsterdamsky, 2013 ).

The charges of the pension funds have attracted considerable public attention and growing criticism, especially since the 2008 mandatory pension arrangement. The criticism has centred on two main issues. The first is the 'horrendous distortion' whereby the weakest and least well-off employees - most of whom joined the private pension funds due to the mandatory pension arrangement - are paying the highest management charges (Arlozerov, 2014). Second, critics argue that the disparity of management charges leads to inequality between savers (Amsterdamsky, 2013).

\section{The regulatory response to the management charges problem}

When the issue of the pension funds' management charges began gaining public momentum, the CMISD refused to tighten its regulation and lower the cap on pension management charges set in the 2003/4 reform. In 2010, in response to a query by the Parliamentary Research Centre on this issue, the CMISD responded that:

Further caps on management charges through regulation could hurt the ability of companies to enter the pensions market, and undermine competition. If competition remains, it should, in the long term, benefit savers in terms of the quality of the pension product, and perhaps also in future reduction of management charges (Schwartz, 2010).

This approach - which is founded on the premise that competition improves the quality of pension products while lowering their price - is nowhere more explicit than in the CMISD's 2010 reform policy document, titled The Plan to Increase Competition (Ministry of Finance, 2010: 2). With regard to management charges, the plan established two new policies. First, in order to 'minimise the differences between pension products, to make it easier to compare them' 
(Ministry of Finance, 2010: 2), the CMISD suggested capping, and ultimately equalising, the maximum management charges in the provident funds and the senior employees' insurance schemes with the other private pension funds. Second, in a bid to prevent practices of hidden costs through the use of temporary discounts in management charges for new savers, it banned all increases in management fee rates within the first two years of joining a fund, and required pension providers to give their clients clear notice of any changes in management charges (Ministry of Finance, 2012a, 2012b).

Another focus of the CMISD was to raise awareness among fund clients, and to empower them when negotiating their charges (Ministry of Finance, 2012a). In its efforts to empower savers, the CMISD launched an advertising campaign to increase the public's awareness of its ability to negotiate over management charges. It also published criteria for comparing pension funds and has, since 2014, published a league table of consumer satisfaction with various pension products (Ministry of Finance, 2014a, 2015a, 2015b). In addition, the CMISD has established a digital system for transferring information between financial institutions, to make it easier for savers to switch from one pension fund to another (Ministry of Finance, 2014a).

Interestingly, even though the issue of lowering management charges per se has attracted the CMISD's attention and treatment, the disparity in management charges between 'strong' and 'weak' employees has been almost completely ignored. Indeed, for a long time this issue was entirely absent from the CMISD's policy documents, and only began receiving regulatory attention when it was raised in the media or in parliamentary debates. Even then, however, it is quite clear that CMISD officials did not see fee disparity as a problem that requires a regulatory response. For example, in response to a media enquiry, it replied:

Different management charges for different savers - particularly for savers belonging to large groups, which are cheaper to manage - is an internationally established practice that reflects competition between providers that benefits savers. (Bindman, 2011).

Public criticism of management charges and of fee disparities is still significant. For low-wage workers, the cap on management charges has often been not just a ceiling but a floor, that is, the highest charges allowed are in practice the lowest fees these workers can expect to pay. Although management charges have generally declined in recent years, these reductions are still mainly limited to organised and high-income earners. Suggestions about establishing pension schemes with low management charges have been rejected in the past, but recently the Ministry of Finance has begun to promote this option.

\section{Discussion}

The findings show that, in both Israel and the UK, market dynamics have led to low-wage workers paying a higher percentage of their savings as management 
charges than high earning or better organised workers. As a result, pension charges are causing significant social concern. One issue is that high management charges significantly erode these workers' savings by eating up a sizeable part of their pension returns in the long run, thereby further undermining the adequacy of their old-age pensions. In addition, these market dynamics create significant disparities in the level of management charges paid by savers, creating new social divisions based on the attractiveness of savers as customers. The outcome whereby the poorer you are, the bigger the portion of your savings you pay in charges - clearly violates progressive notions of social justice.

In both countries, this has resulted in regulatory interventions, though the aims, tools, and underlying perceptions of the regulatory role differ considerably. In the UK, the aims of the regulatory reforms have been articulated much more explicitly in 'social' terms - such as 'protecting the poorest, and being fair to women and carers, to savers, and between generations' (DWP, 2006: 15). Fairness is seen not only as preventing fraud or mistreatment, but also protecting the poor and rectifying inequities. The goals of giving low-wage workers the opportunity to save and making the system fair by ensuring access to high-quality, low-cost provision to all were central to the creation of NEST. This is most apparent in the fact that the benchmark for the appropriate level of charges in NEST was set according to the market rates paid by high-earning workers at the time. In that respect, NEST has a clear equalising agenda.

In Israel, on the other hand, the aims of regulating pension charges were less socially ambitious from the outset. The government began the privatisation reform by capping management charges at 6 per cent of monthly contributions, and an annual amount of 0.5 per cent of the total value of the fund - higher than the previous cap, and certainly higher than that set for NEST in the UK. When the issue of management charges arose again after the 2008 mandatory pension reform, regulatory intervention was explained in economic regulation terms - namely, correcting market failures and the need to increase transparency. Moreover, records show that the CMISD initially did not consider the disparity of management charges to be a problem, but merely the normal manner in which markets function. Even recently, when it began treating the disparity of management charges as a problem, this has not been accompanied by any clear objectives of equalising management charges.

An interesting difference between the two cases is their respective approaches to the goal of increasing coverage for occupational pensions. In Israel, in keeping with traditional social democratic welfare state thinking of social regulation through labour law, occupational pension saving has been made mandatory making low-income savers a 'captive audience': even though they may choose between providers, they cannot choose to 'exit' the pension market entirely. In the UK, in a more liberal 'nudging' approach, workers are strongly encouraged to join pension funds through automatic enrolment but may still opt out. The 
creators of NEST have had to 'woo' consumers to ensure they do not opt out of the programme. Thus, paradoxically, the more liberal UK approach has created a greater drive to lower pension charges to make pensions more attractive for low-wage workers. While in Israel most low-income savers pay the maximum charges allowed in law, i.e., 6 per cent of the monthly contribution and an additional annual management charge of 0.5 per cent of the total value of the fund (Ministry of Finance, 2014b), NEST offers low-income workers charges of 1.8 per cent on each new contribution and an annual management charge of 0.3 per cent of the total value of the fund (Work and Pensions Committee, 2015).

Coming back to the analytical and theoretical framework above, it may be argued that each case represents different social policy aims and tools. As mentioned, social citizenship in the traditional provider welfare state may play out as minimal or more adequate levels of de-commodification: weak commitment to egalitarianism in liberal welfare states leads to poor relief arrangements, while stronger forms of egalitarianism in social democratic welfare states lead to universal and adequate benefits and services. The UK and Israeli cases suggest these different logics of social citizenship can apply in the realm of regulatory welfare as well (what may referred to as 'regulatory citizenship'), even though in the regulatory context, the goal is to regulate the access to goods and services delivered by the market rather than providing the service itself (Leisring and Mabbett, 2011). In the Israeli case, the regulatory effort focuses on empowering low-wage workers as customers by strengthening their bargaining position, while direct regulation is used only to offer them a minimal level of social protection (capping the level of charges, yet setting the cap at a relatively high level). In the UK, NEST offers low-income workers access to more adequate pension charges, previously reserved for high-income and organised workers.

Thus, our findings show access to pensions may be regulated so as to achieve a minimally acceptable level of conditions (the Israeli case), or regulation may take a more egalitarian approach, aiming to provide customers with access to highlevel market terms, in the effort to equalise access to market goods and services (the NEST case). As social regulation is usually used to provide minimal social protection, as explained in the theoretical section, this seems to point to another step in socialising the regulatory state - though it is still limited to redistribution between service providers and savers, not aimed at broader redistribution.

The two countries also differ in the strategies they use in combining various policy tools and methods of delivery. In the UK, after several futile attempts to lower management charges, including the 'stakeholder pensions', the DWP devised NEST as a new strategy of intervention - a pension saving scheme, operated by a public corporation and offering low charges as its raison d'être. In Israel, regulation tools have combined traditional legal intervention means of capping management charges with consumer empowerment tools aimed at increasing awareness and providing information to facilitate informed choice by customers. 
TABLE 1. Strategies of service provision in the regulatory welfare state vs. the provider state

\begin{tabular}{|c|c|c|}
\hline & Public Financing & Legal Regulatory Tools \\
\hline \multirow[t]{2}{*}{ Public Delivery } & $\begin{array}{l}\text { Provider State } \\
\quad \text { - Public benefits and } \\
\quad \text { services }\end{array}$ & $\begin{array}{l}\text { Public Option } \\
\text { - State-run (but not } \\
\text { funded) services } \\
\text { operating within the } \\
\text { market }\end{array}$ \\
\hline & Example: $\begin{array}{c}\text { First tier public } \\
\text { old-age pensions }\end{array}$ & Example: $\quad$ NEST, UK \\
\hline \multirow[t]{2}{*}{ Private Proxies } & $\begin{array}{l}\text { Quasi-Markets } \\
\text { - Contracting out and } \\
\quad \text { voucher arrangements }\end{array}$ & $\begin{array}{l}\text { Regulated Market Provision } \\
\text { - Caps on prices and social } \\
\text { tariffs } \\
\text { - Prevention of service } \\
\text { disconnection } \\
\text { - Products defined by } \\
\text { regulation }\end{array}$ \\
\hline & 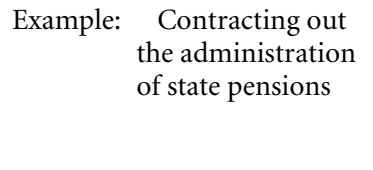 & $\begin{array}{l}\text { Examples: Caps on } \\
\text { pension scheme } \\
\text { charges, } \\
\text { Israel; stakeholder } \\
\text { pensions, UK }\end{array}$ \\
\hline
\end{tabular}

Unlike the UK, where the employers of low-income savers are given an option to choose a publicly-run low-fee pension product, in Israel, the responsibility for reducing the charges rests on the shoulders of the individual saver.

These differences may allow wider discussions of the strategies used in the regulatory welfare state by distinguishing between public financing and legal regulatory tools and between styles of service delivery: public delivery or private proxies. The intersection of these different kinds of tools and delivery methods, as presented in Table 1, creates an analytical framework incorporating the traditional provider state with three strategies of the regulatory welfare state. Two of these strategies have already been identified in the literature, as elaborated in the theoretical section. The first strategy is quasi-markets, whereby the state funds services delivered by the market. This model is usually used in the delivery of in-kind social services, not in the payment of benefits such as old age pensions. However, it is interesting to note that recently in the UK, the DWP Efficiency Review suggested private firms could be brought in to administer state pensions as a means of cost cutting (Malik, 2014). Although the review was not officially published, and the DWP said there were currently no plans to outsource the pension service, this is a good theoretical example of quasi-markets in the realm of pensions. The second is regulated market provision, whereby legal regulation is used to secure access to services through market provision - with no direct public financing. In the pension context, this represents efforts to cap pension charges as in Israel, or to design pension products through regulation to later be delivered by the market, as in the UK's stakeholder pensions. 
NEST contributes an empirical example of a third service provision strategy of the regulatory welfare state which is usually overlooked in the theoretical conceptualisation of the regulatory welfare state: a public option in the market. This strategy allows the state to play an active role in initiating a new public service to address a social problem - thus countering the general trend towards privatisation. However, in line with the regulatory state approach, it is designed to operate within a market environment and to pay for itself financially with no significant public tax-based funding.

The turn to the public option alternative seems to signify another stage in the dynamics of applying welfare state logic to the regulatory state, one stemming from growing scepticism about the ability of economic regulation and customer protection tools to effect a significant reduction in pension charges for low-wage savers. In previous years, UK regulators believed competition and transparency would be enough to resolve the issue of high pension fund charges (Mabbett, 2011). It took time and experience for regulators to realise this problem was rooted in the structure of the pension market and required a more radical solution. They now recognise that for private pension firms, low-income savers are often simply not attractive enough as customers; therefore, it is not enough to give these savers better information or to allow them to switch funds more easily.

NEST suggests the possibilities of a new policy tool, in which public provision is not an alternative to the market, as the welfare state was originally conceived, but a public alternative within the market. It creates a different balance of responsibilities between the state, pension savers and pension providers. Contrary to the trend of shifting responsibility to the savers, the state takes more responsibility by offering savers an option of low-fee pensions, rather than merely empowering their market position through education and information. In that respect, the innovation of offering a public option of low-cost pensions mitigates the tension between setting this higher social policy goal and retaining the market setting and avoiding strong, legal, regulatory control over the prices offered by private pension providers.

However, the differences between the two cases should not be overstated. In 2015, a cap on default occupational schemes ( 0.75 per cent of the total fund value) was introduced in the UK (The Pensions Regulator, 2015). This demonstrates that NEST has not been a silver bullet solution to the pension charges problem, and highlights, perhaps, a further realisation by UK regulators of the limitations of market provision, even a market in which a public option is operating.

\section{Conclusion}

The study illustrates the complex interaction between the regulatory state and the welfare state in the field of private pensions. It reinforces former findings (Leisering and Mabbett, 2011) that, contrary to the view of the World Bank, 
the pension market cannot function purely as an autonomous, market-driven sphere. Political pressures influence the regulation of pensions, causing welfare state norms and institutions to blend into the regulatory state. In terms of the goals of regulatory welfare, the analysis of the UK and Israeli cases demonstrates regulatory welfare can be aimed not only at providing minimal protection, but also at adopting more egalitarian goals that aspire to equalise the access of different kinds of customers to services provided in the market. This is an important point as, to date, research on regulatory welfare has found most regulatory interventions aim to provide minimal social protection.

On the institutional level, we suggest there are actually three types of regulatory welfare state strategies, each one distinctive in terms of its fiscal vs. legal regulatory tools and public vs. private delivery. This analytical framework, we believe, provides a more nuanced understanding of how the state may pursue the provision of social welfare. This includes the emergence of public option arrangements, such as NEST, enabling the state to assume greater responsibility for low-income savers while maintaining the market structure and minimising direct regulation of private providers.

The study suggests that regulatory citizenship, like industrial citizenship, can serve as an alternative path for de-commodification and the establishment of social rights not based on direct state funding or provision. The social impact of regulatory citizenship should not be overstated, however. Regulatory citizenship in the cases studied is restricted to redistribution between service providers and savers, not between pension savers of different kinds or between pension savers and the general tax payer. The societal impact of such policies can be expected to be limited in terms of long-term savings, especially - as in the Israeli case - when the regulators' perception of their role is limited to minimal social protection. Moreover, as long as pensions themselves remain market dependent, most of the social risk and instability of marketisation are still assumed by the individual saver. This reinforces the notion that, even when regulatory welfare means are in place, there is a continued need for traditional redistributory and collectively financed forms of social protection (Taylor-Gooby et al., 2004).

\section{References}

Amsterdamsky, S. (2013), 'We are the $66 \%$ who pay for $10 \%$ of the savers for pension', Calcalist, Israel. (Hebrew)

Arlozerov, M. (2014), 'The 750 thousand suckers who pay the highest management charges in pension', The Marker, Israel. (Hebrew)

Benish, A. (2010), 'Re-bureaucratizing welfare administration,' Social Service Review, 84 (1): 77-101.

Benish, A. (2014), 'Outsourcing, Discretion, and Administrative Justice: Exploring the Acceptability of Privatized Decision Making. Law \& Policy, 36: 2, 113-133.

Benish, A. and Levi-Faur, D. (2012), 'New forms of administrative law in the age of third-party government,' Public Administration 90: 4, 886-900. 
Haber, H. (2011), 'Regulating-for-Welfare: A Comparative Study of "Regulatory Welfare Regimes" in the Israeli, British, and Swedish Electricity Sectors', Law \& Policy, 33: 1, $116-148$.

Haber, H. (2015), 'Regulation as Social Policy: Home Evictions and Repossessions in The UK and Sweden', Public Administration, 93: 3, 806-821.

Haber, H. (2016), 'Rise of the Regulatory Welfare State? Social Regulation in Utilities in Israel', Social Policy \& Administration.

Berner, F. (2011), 'New Private Pensions in Germany: A Pension Market or a Branch of the Welfare State? Contested Regulatory Issues', in L. Leisering (ed.), The New Regulatory State, New York: Palgrave Macmillan.

Bindman, R. (2011), 'Inequality in pension savings: The strong save, small companies' workers pay', Calcalist, Israel. (Hebrew)

Dean, H. (2015), Social Rights and Human Welfare, London: Routledge.

DWP (2006), Security in Retirement: Towards a New Pensions System, London: DWP.

DWP (2013), Supporting automatic enrolment, London: DWP.

Ebbinghaus, B. (ed.) (2011), The Varieties of Pension Governance: Pension Privatization in Europe, New York: Oxford University Press.

Esping-Andersen, G. (1990), The Three Worlds of Welfare Capitalism, Princeton: Princeton University Press.

Frericks, P. (2013), "Strengthening Market Principles in Welfare Institutions: How Hybrid Pension Systems Impact on Social-risk Spreading", Journal of Social Policy, 42: 4, 665-683.

Gal, J. (2002), 'How well does a partnership in pensions really work?', Ageing and Society, 22: 2, $161-183$.

Gal, J. (2010), 'Is there an extended family of Mediterranean welfare states?', Journal of European Social Policy, 20: 4, 283-300.

Gilbert, N. (2005), 'The "Enabling State?" from Public to Private Responsibility for Social Protection', OECD Social, Employment and Migration Working Papers, Working Paper No. 26, OECD.

Le Grand, J. (1991), 'Quasi-Markets and Social Policy', The Economic Journal, 101: 408, 12561267.

Leimgruber, M. (2012), 'The Historical Roots of a Diffusion Process: The Three-Pillar Doctrine and European Pension Debates (1972-1994)', Global Social Policy, 12: 1, 24-44.

Leisering, L. (2011), 'Transformation of the State: Comparing the New Regulatory State to the Post-War Provider State', in L. Leisering (ed.), The New Regulatory State, New York: Palgrave Macmillan.

Leisering, L. (2012), 'Pension privatization in a welfare state environment: socializing private pensions in Germany and the United Kingdom', Journal of Comparative Social Welfare, 28: 2, 139-151.

Leisering, L. and Mabbett, D. (2011), 'Introduction: Towards a New Regulatory State in Old-Age Security? Exploring the Issues', in L. Leisering (ed.), The New Regulatory State, New York: Palgrave Macmillan.

Levi-Faur, D. (2013), 'The Odyssey of the Regulatory State: From a "Thin" Monomorphic Concept to a "Thick" and Polymorphic Concept', Law and Policy, 35: 1-2, 29-50.

Levi-Faur, D. (2014), 'The Welfare State: A Regulatory Perspective', Public Administration, 92: 3, 599-614.

Levi-Faur, D. and Gilad, S. (2004), 'The rise of the British regulatory state: Transcending the privatization debate', Comparative Politics, 37: 1, 105-124.

Lurie, L. (2015), 'The Privatization of the Occupational Pension in Israel', Jerusalem: The Van Leer Jerusalem Institute, in I. Galnoor, A. Paz-Fuchs and N. Zion (Eds.), Privatization Policy in Israel: State Responsibility and the Boundaries between the Public and the Private, Jerusalem: Van Leer Institute

Mabbett, D. (2010), 'The Regulatory Rescue of the Welfare State', in D. Levi-Faur (ed.), Handbook of the Politics of Regulation, Cheltenham: Edward Elgar Publishing Limited. 
Mabbett, D. (2011), 'The Regulatory Politics of Private Pensions in the UK and Germany', in L. Leisering (ed.), The New Regulatory State, New York: Palgrave Macmillan.

Mabbett, D. (2012), 'The Ghost in the Machine Pension Risks and Regulatory Responses in the United States and the United Kingdom'. Politics \& Society, 40: 1, 107-129.

Majone, G. (1997), 'From the positive to the regulatory state: Causes and consequences of changes in the mode of governance', Journal of Public Policy, 17: 2, 139-167.

Malik, S. (2014), 'State pension service could be privatised under DWP plans', The Guardian, UK.

Mann, K. (2005), 'Three Steps to Heaven? Tensions in the Management of Welfare: Retirement Pensions and Active Consumers', Journal of Social Policy, 39: 1, 77-96.

Marschallek, C. (2011), 'Back to the State? The Public Policies of Private and Public Pensions in Britain', in L. Leisering (ed.), The New Regulatory State, New York: Palgrave Macmillan.

Meyer, T. and Bridgen, P. (2012), 'Business, Regulation and Welfare Politics in Liberal Capitalism', Policy \& Politics, 40: 3, 387-403.

Ministry of Finance, CMISD (2010), A Plan to Increase Competition in the Pension Market, Jerusalem: Ministry of Finance. (Hebrew)

Ministry of Finance, CMISD (2012a), Annual Report 2011, Jerusalem: Ministry of Finance. (Hebrew)

Ministry of Finance, CMISD (2012b), Management Charges in Pension Saving Devices (Financial Institutions Circular 22-9-2012), Jerusalem: Ministry of Finance. (Hebrew)

Ministry of Finance, CMISD (2014a), Annual Report 2013, Jerusalem: Ministry of Finance. (Hebrew)

Ministry of Finance, CMISD (2014b), Presentation on Management Charges Calculator, Jerusalem: Ministry of Finance. (Hebrew)

Ministry of Finance, CMISD (2015a), Annual Report 2014, Jerusalem: Ministry of Finance. (Hebrew)

Ministry of Finance, CMISD (2015b), The Pension Guide, Jerusalem: Ministry of Finance. (Hebrew)

Naczyk, M. and Seeleib-Kaiser, M. (2015), 'Solidarity against All Odds Trade Unions and the Privatization of Pensions in the Age of Dualization', Politics and Society, 43: 3, 361-384.

OECD (2009), Private Pensions Outlook 2008, OECD Publications.

Pensions commission (2005), A New Pension Settlement for the Twenty-First Century, London: TSO.

Schwartz, E. (2010), Management charges in Provident Funds and Pension Funds, Jerusalem: The Research and Information Center of the Knesset. (Hebrew)

Taylor-Gooby, P. (2011), 'Limits to the Regulated Market: The UK Experiment', in L. Leisering (ed.), The New Regulatory State, New York: Palgrave Macmillan.

Taylor-Gooby, P., Larsen, T., and Kananen, J. (2004), 'Market means and welfare ends: the UK welfare state experiment', Journal of Social Policy, 33: 4, 573-592.

The Pensions Regulator (2015), The essential guide to governance standards and charge controls, London: The Pensions Regulator.

Trampusch, C. (2007), 'Industrial Relations as a Source of Social Policy: A Typology of the Institutional Conditions for Industrial Agreements on Social Benefits', Social Policy \& Administration, 41: 251-270.

Work and Pensions Committee (2015), Progress with Automatic Enrolment and Pension Reforms, London: The Stationery Office Limited. 